\title{
Article \\ In Silico, Combined Plasmonic Photothermal and Photodynamic Therapy in Mice
}

\author{
Georgios Kareliotis*(D), Eleni Chronopoulou and Mersini Makropoulou
}

check for updates

Citation: Kareliotis, G.;

Chronopoulou, E.; Makropoulou, M. In Silico, Combined Plasmonic

Photothermal and Photodynamic

Therapy in Mice. J. Nanotheranostics 2022, 3, 39-54. https://doi.org/ $10.3390 /$ jnt3010004

Academic Editor: Moein Moghimi

Received: 9 December 2021

Accepted: 23 February 2022

Published: 28 February 2022

Publisher's Note: MDPI stays neutral with regard to jurisdictional claims in published maps and institutional affiliations.

Copyright: (C) 2022 by the authors. Licensee MDPI, Basel, Switzerland. This article is an open access article distributed under the terms and conditions of the Creative Commons Attribution (CC BY) license (https:// creativecommons.org/licenses/by/ $4.0 /)$.

\author{
Laser Development and Applications Team, Physics Department, School of Applied Mathematical and \\ Physical Sciences, National Technical University of Athens, Zografou Campus, 15780 Athens, Greece; \\ helenchrono2@gmail.com (E.C.); mmakro@central.ntua.gr (M.M.) \\ * Correspondence: kareliotis.g@gmail.com
}

\begin{abstract}
Plasmonic photothermal and photodynamic therapy (PPTT and PDT, respectively) are two cancer treatments that have the potential to be combined in a synergistic scheme. The aim of this study is to optimize the PPTT treatment part, in order to account for the PDT lack of coverage in the hypoxic tumor volume and in cancer areas laying in deep sites. For the needs of this study, a mouse was modeled, subjected to PDT and its necrotic area was estimated by using the MATLAB software. The same procedure was repeated for PPTT, using COMSOL Multiphysics. PPTT treatment parameters, namely laser power and irradiation time, were optimized in order to achieve the optimum therapeutic effect of the combined scheme. The PDT alone resulted in $54.8 \%$ tumor necrosis, covering the upper cancer layers. When the PPTT was also applied, the total necrosis percentage raised up to 99.3\%, while all of the surrounding studied organs (skin, heart, lungs and trachea, ribs, liver and spleen) were spared. The optimized values of the PPTT parameters were $550 \mathrm{~mW}$ of laser power and $70 \mathrm{~s}$ of irradiation time. Hence, the PPTT-PDT combination shows great potential in achieving high levels of tumor necrosis while sparing the healthy tissues.
\end{abstract}

Keywords: plasmonic photothermal therapy (PPTT); photodynamic therapy (PDT); nanoparticles

\section{Introduction}

Cancer is a disease that, unfortunately, affects the lives of numerous people around the globe, while its complexity leads to a need for targeted and complex therapeutic approaches. As a result, the current research trend is towards combination therapies rather than monotherapies [1]. In the field of non-ionization radiation therapies, plasmonic photothermal therapy (PPTT) and photodynamic therapy (PDT) hold key roles, along with other well-established treatments (e.g., ultrasound and microwave hyperthermia). Indeed, all the aforementioned therapeutic approaches have shown adequate and promising results, but on the other hand, they do have limitations [1-3].

Photothermal is one of the oldest therapies, dating back to 1700 B.C. [4]. Even the father of medicine, Hippocrates, had acknowledged its value, stating in Aphorism (7.87) that "Those diseases which medicines do not cure, iron cures; those which iron cannot cure, fire cures; and those which fire cannot cure, are to be reckoned wholly incurable". It is based on hyperthermia, namely the temperature increase that will lead to apoptotic or necrotic procedures and hence, tumor destruction $[4,5]$. Although rarely used as monotherapy, it has been included in the 2013 guidelines of the National Comprehensive Cancer Network $(\mathrm{NCCN})$ as a choice for breast cancer recurrence [6]. The conventional heat sources used in hyperthermia include radio- and microwaves, ultrasound as well as beams in the visible and infrared spectrum of the electromagnetic radiation [4,7]. An inherent obstacle to hyperthermia implementation is the relatively low energy absorption values from the soft tissues and the absence of localized action [7]. The latter can be overcome through plasmonic photothermal therapy, which takes advantage of the localized plasmonic phenomena. It is 
based on the administration of metal nanoparticles (NPs), usually gold (AuNPs), which, due to their size and coating, accumulate mainly in the cancer area. When irradiated with light of the appropriate wavelength, localized surface plasmon resonance (LSPR) can occur [8]. This is the result of the strong photon absorption, leading to coherent electron oscillation around the metal surface and therefore, a significant temperature increase. The phenomenon practically depends on factors affecting surface electron density, such as, for example, NPs shape and size, as well as the dielectric constant of the metal and the surrounding medium $[4,9]$. Thus, gold, silver and copper nanospheres display LSPR in the visible part of the electromagnetic spectrum, while nanoshells present red shift. Finally, it is worth noting that, due to the recent development of PPTT and since the available data originate from studies with large differentiation in terms of methodology [10], its dosimetry cannot be addressed under a single approach.

Photodynamic therapy can be considered as a light-activated, targeted chemotherapy, originating in the early 1900's [11,12]. It is based on three fundamental agents that act dynamically and simultaneously. First, a photosensitive substance, namely a photosensitizer (PS), which accumulates selectively in the cancer area, is administered to the patient. Afterwards, the area is irradiated with the light of an appropriate wavelength that matches the PS absorption spectrum. The PS absorbs the incident photon energy and interacts with the molecular oxygen (Type II mechanism), producing a reactive oxygen species (ROS) and especially oxygen molecules that are in their lower excited state, namely singlet oxygen $\left({ }^{1} \mathrm{O}_{2}\right)$, which is highly cytotoxic. Since light is topically applied and the diffuse radius of singlet oxygen is in the order of $100 \mathrm{~nm}$ [13], PDT has a highly targeted outcome. On the other hand, light absorption and scattering by numerous tissues chromophores lead to a limited penetration depth, which is the main drawback of PDT. As a result, the main applications of PDT in cancer concern skin or endoscopically accessible areas (e.g., lungs, esophagus) [14-16]. As far as the destruction of cancer cells is concerned, three main pathways exist, namely the direct cell damage, the vascular shutdown and the activation of the immune response [17]. Various factors determinate which pathway will take place and through what mechanism (necrosis, apoptosis or autophagy), such as, for example, the PS kind and its intracellular concentration site, the type of cancer and the light fluence rate and thus, the complete phenomenon cannot always be precisely defined [17-19].

It is obvious that each of the aforementioned therapies has its advantages, but also its drawbacks. Hence, a promising approach is to combine both in a synergistic treatment scheme. Although the available literature is poor in clinical trials in the field, experimental results from studies are quite encouraging [1]. Therefore, this work focused on the combined therapeutic outcome that PPTT and PDT can achieve, based on a computational approach on a mouse model. The PPTT part of the treatment was optimized in order to account for the main drawback that PDT has, namely the poor necrosis in tumor areas laying in deep sites. Firstly, PDT was simulated to detect the tumor areas with poor necrosis coverage. Afterwards, PPTT was implemented in order to treat these areas. Finally, the total outcome was assessed.

\section{Materials and Methods}

\subsection{Animal Model}

A NOD SCID (nonobese diabetic/severe combined immunodeficient) mouse, bearing a $4 \mathrm{~T} 1$ breast cancer tumor was modeled. The tumor, of a radius of $0.2 \mathrm{~cm}$, was assumed between its front legs, slightly projecting out of the body contour, as shown in Figure 1. For the PPTT, the whole mouse was 3D-implemented in COMSOL Multiphysics ${ }^{\circledR}$ (Stockholm, Sweden) (see Figure 1a-c), with its skin, muscle tissue, basic bone structures, heart, lungs, trachea, liver and spleen. The software choice was based on its great capabilities of designing realistic models and its ability to study complex biophysical phenomena. For the PDT, the mouse was implemented in MATLAB (The MathWorks, Inc., Natick, MA, United States) in a 2D geometry, as shown in Figure 1d. At this point, the reader should have in mind that in contrast to COMSOL, MATLAB uses mathematic formulas and 
logical/conditional expressions in order to create every single part of the geometry, making a realistic, 3D representation of the animal rather challenging. Since the penetration depth of the light used in PDT is limited, hence also is the PDT action, and the simulation can be implemented/focused on the tumor and a few millimeters around it.

(a)

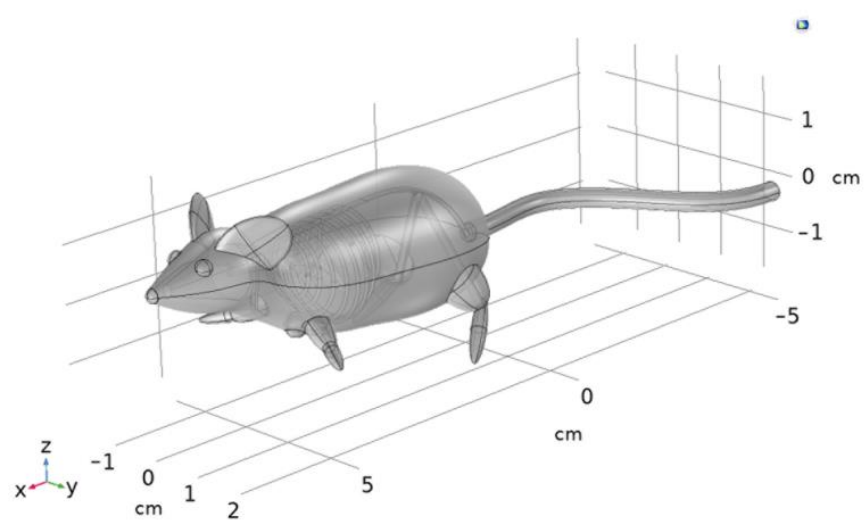

(c)

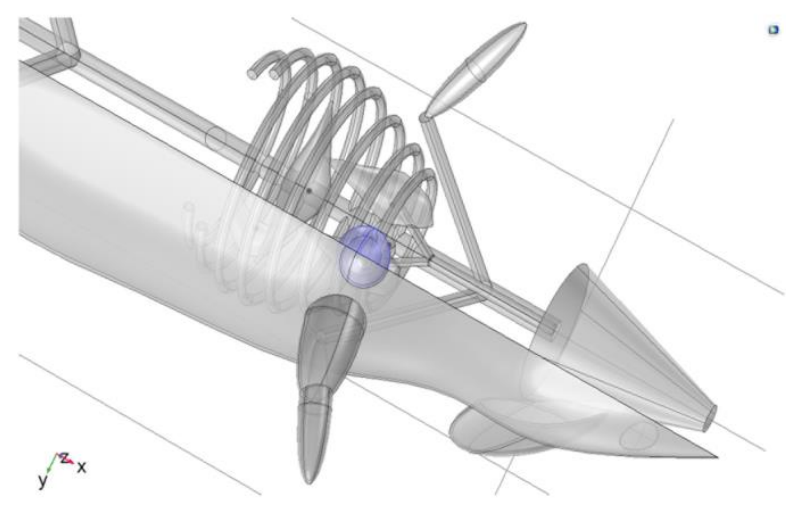

(b) Mouse model (inverted)

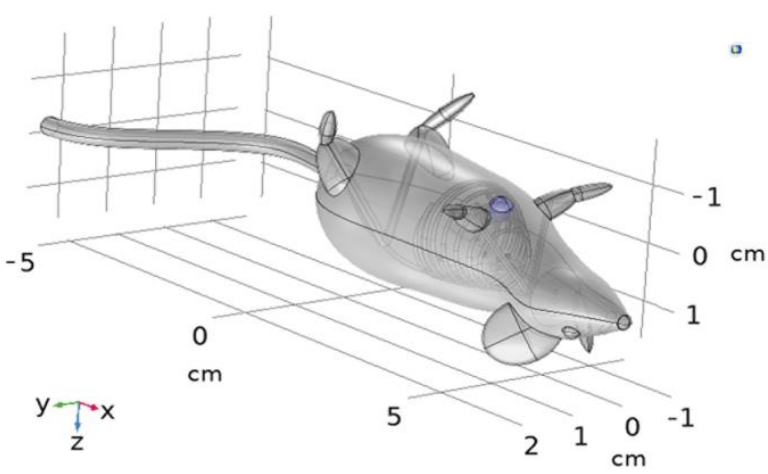

(d)

Sagittal slice of tumor

Tissue types

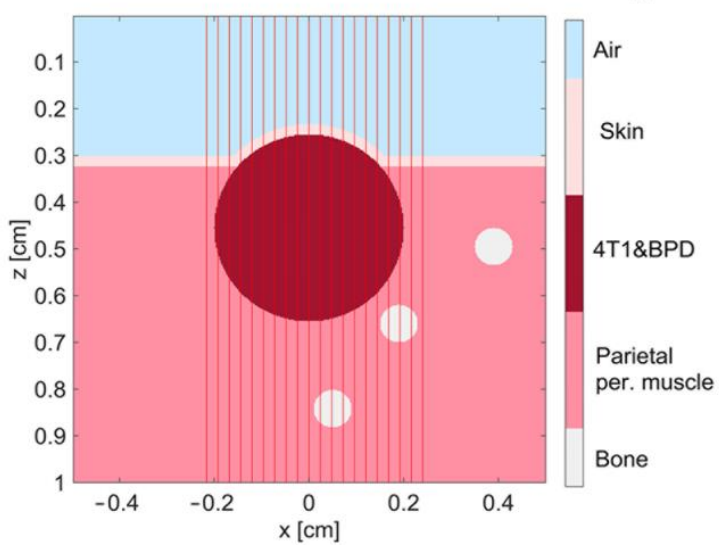

Figure 1. (a,b) The mouse model in two different orientations and (c) zoomed area of the mouse model, as implemented in COMSOL Multiphysics ${ }^{\circledR}$. (d) Sagittal slice of the tumor area, created in MATLAB. The three white dots correspond to nearby ribs, while the vertical red lines are a visual representation of the incident laser beam.

\subsection{PDT Model}

\subsubsection{Computational Simulation}

The computational simulation was based on a former published code of our team [20,21], which simulates the PDT effect on cancer tissue. It utilizes Monte Carlo simulations to assess the spatial profile of the light fluence rate into tissue (mcxyz.c, version July 22, 2019, created by Jacques S., Li T., and Prahl S., available from: https:/ / omlc.org/software/mc/mcxyz/ index.html, accessed on: 16 November 2021) and a system of differential photochemical equations (see Equations (1)-(3)) that describe the Type II PDT mechanism [22]. The latter assesses the photodynamic action through scripts, coded in MATLAB, using a desktop computer with an Intel ${ }^{\circledR}$ Core $^{\mathrm{TM}}$ i7-4790 @ $3.60 \mathrm{GHz}$ processor and $16 \mathrm{~GB}$ of RAM. The aforementioned simulation was implemented using $0.025 \mathrm{~mm}$ of bin size.

$$
\frac{d\left[S_{0}\right]}{d t}+\left(\xi \sigma \frac{\varphi\left(\left[S_{0}\right]+\delta\right)\left[{ }^{3} O_{2}\right]}{\left[{ }^{3} O_{2}\right]+\beta}\right)\left[S_{0}\right]=0,
$$




$$
\begin{gathered}
\frac{d\left[{ }^{3} \mathrm{O}_{2}\right]}{d t}+\left(\xi \frac{\varphi\left[S_{0}\right]}{\left.\xi{ }^{3} \mathrm{O}_{2}\right]+\beta}\right)\left[{ }^{3} \mathrm{O}_{2}\right]-g\left(1-\frac{\left[{ }^{3} \mathrm{O}_{2}\right]}{\left[{ }^{3} \mathrm{O}_{2}\right]_{0}}\right)=0, \\
\frac{d\left[{ }^{1} \mathrm{O}_{2}\right]_{r x}}{d t}-f\left(\xi \frac{\varphi\left[S_{0}\right]\left[{ }^{3} \mathrm{O}_{2}\right]}{\left[{ }^{3} \mathrm{O}_{2}\right]+\beta}\right)=0 .
\end{gathered}
$$

In the above equations, $\left[S_{0}\right]$ stands for the concentration of ground-state photosensitizer, $(t)$ for the irradiation time, $(\xi)$ for the specific oxygen consumption rate, $(\sigma)$ for the specific photobleaching ratio, $(\varphi)$ for the light fluence rate, $(\delta)$ for the low concentration correction, $\left[{ }^{3} \mathrm{O}_{2}\right]$ for the concentration of molecular oxygen, $(\beta)$ for the oxygen quenching threshold, $(g)$ for the oxygen supply rate to tissue, $\left[{ }^{3} \mathrm{O}_{2}\right]_{0}$ for the initial concentration of molecular oxygen, $\left[{ }^{1} \mathrm{O}_{2}\right]_{r x}$ for the concentration of singlet oxygen leading to cell death (apparent reacted singlet oxygen), $(f)$ for the fraction of ${ }^{1} \mathrm{O}_{2}$ interacting with target and $\left[{ }^{1} \mathrm{O}_{2}\right]_{r x, s h}$, for the threshold concentration of singlet oxygen leading to cell death.

\subsubsection{Photosensitizer and Parameters}

The PDT-simulated treatment was conducted using Visudyne ${ }^{\circledR}$, a photosensitive agent that has been studied in cancer clinical trials (clinicaltrials.gov, No. NCT02939274, NCT02464761). Its active substance is verteporfin, a lipophilic benzoporphyrin monoacid derivative (BPD-MA). The treatment parameters were chosen based on the available literature on in vivo experiments, which are summarized in Table 1 . The light source modeled a real point source of our laboratory, with emission wavelength $\lambda=680 \mathrm{~nm}$, power $P=60 \mathrm{~mW}$ and fluence rate $\varphi=167 \mathrm{~mW} / \mathrm{cm}^{2}$. Irradiation time was set at $15 \mathrm{~min}$, resulting in $150.3 \mathrm{~J} / \mathrm{cm}^{2}$, which is in the range of values regarded as adequate to result in a good treatment outcome [23]. As far as PS dose is concerned, $1 \mathrm{mg} / \mathrm{kg}$ per body weight (b.w.) was assumed, injected via a $100 \mu \mathrm{L}$ aqueous solution.

Table 1. Basic parameter values of in vivo verteporfin-PDT in mice.

\begin{tabular}{cccccc}
\hline $\begin{array}{c}\text { Total Light Dose } \\
\left(\mathbf{J} / \mathbf{c m}^{2}\right)^{*}\end{array}$ & $\begin{array}{c}\text { Fluence Rate } \\
\left(\mathbf{m W} / \mathbf{c m}^{2}\right)^{*}\end{array}$ & $\begin{array}{c}\text { Irradiation } \\
\text { Time }(\mathbf{m i n})\end{array}$ & $\begin{array}{c}\text { Dose } \\
(\mathbf{m g} / \mathbf{k g})\end{array}$ & $\begin{array}{c}\text { Injected } \\
\text { Volume }(\boldsymbol{\mu L})\end{array}$ & Refs. \\
\hline $20(\mathrm{~J} / \mathrm{cm})$ & $74(\mathrm{~mW} / \mathrm{cm})$ & 4.5 & 1 & 75 & {$[24]$} \\
40 & - & - & 2 & - & {$[25]$} \\
120 & - & - & 1 & - & {$[26]$} \\
$22.5-135(\mathrm{~J} / \mathrm{cm})$ & $12-150(\mathrm{~mW} / \mathrm{cm})$ & - & $0.17-0.99(\mu \mathrm{M})$ & - & {$[27]$} \\
$100-250$ & $50-150$ & $15-45$ & 1 & - & {$[28]$} \\
- & $12-150$ & $3-100$ & 1 & - & {$[29]$} \\
- & $12-150(\mathrm{~mW} / \mathrm{cm})$ & $3-100$ & 1 & - & {$[30]$} \\
\hline
\end{tabular}

* In some studies units differ due to linear light sources.

The values of the optical parameters used in the computational simulation (see Table 2) were partially based on the ones used in a former preliminary study of our team [31] through extrapolation methods, as well as on references [32-34]. The absorption coefficient $\left(\mu_{a}\right)$ of verteporfin, needed for the Monte Carlo simulations, was estimated using its molar concentration $(C)$ and extinction coefficient $(\varepsilon)$, as: $\mu_{a}=\ln (10) \cdot C \cdot \varepsilon$ [35]. For the calculation of $C$, the mass concentration $(1 \mathrm{mg} / \mathrm{kg}$ per b.w., in a $100 \mu \mathrm{L}$ liquid volume) and the molecular weight $(718.8 \mathrm{~g} / \mathrm{mol})$ were taken into consideration [36]. To extract the $\varepsilon$ value, which varies with the wavelength used, data from reference [37] were used. As far as the scattering coefficient $\left(\mu_{s}\right)$, anisotropy factor $\left(g_{f}\right)$ and refractive index $(n)$ values are concerned, they are not available in the literature, to the best of our knowledge and, hence, they were assumed to be the same as the ones of the surrounding medium (4T1 tumor). Finally, the photochemical properties of the PS are summarized in Table 2. 
Table 2. Optical and photochemical properties of the PDT simulation model.

\begin{tabular}{|c|c|c|c|c|}
\hline Layer & Parameter & Value & Parameter & Value $^{a}$ \\
\hline Skin & $\begin{array}{l}\mu_{a} \\
\mu_{s} \\
g_{f} \\
d\end{array}$ & $\begin{array}{c}0.94 \mathrm{~cm}^{-1} \\
37.1 \mathrm{~cm}^{-1} \\
0.8 \\
220 \mu \mathrm{m}\end{array}$ & $\begin{array}{l}\varepsilon \\
\xi \\
\sigma \\
\beta \\
f\end{array}$ & $\begin{array}{c}0.071\left(\mathrm{~cm}^{-1} \mu \mathrm{M}^{-1}\right) \\
55 \times 10^{-3}\left(\mathrm{~cm}^{2} \mathrm{~mW}^{-1} \mathrm{~s}^{-1}\right) \\
1.7 \times 10^{-5}\left(\mu \mathrm{M}^{-1}\right) \\
11.9(\mu \mathrm{M}) \\
1\end{array}$ \\
\hline $4 \mathrm{~T} 1$ tumor & $\begin{array}{c}\mu_{a} \\
\mu_{s} \\
g_{f} \\
r\end{array}$ & $\begin{array}{c}0.76 \mathrm{~cm}^{-1} \\
98.0 \mathrm{~cm}^{-1} \\
0.9 \\
0.2 \mathrm{~cm}\end{array}$ & $\begin{array}{c}\delta \\
g_{0} \\
{\left[{ }^{3} \mathrm{O}_{2}\right]_{0}} \\
{\left[{ }^{1} \mathrm{O}_{2}\right]_{r x, 0}{ }^{c}} \\
{\left[{ }^{1} \mathrm{O}_{2}\right]_{r x, s h}}\end{array}$ & $\begin{array}{c}33(\mu \mathrm{M}) \\
0.7\left(\mu \mathrm{M} \mathrm{s}^{-1}\right)^{\mathrm{b}} \\
60(\mu \mathrm{M}) \\
0 \\
400(\mu \mathrm{M})\end{array}$ \\
\hline BPD-MA & $\begin{array}{l}\mu_{a} \\
\mu_{s} \\
g_{f}\end{array}$ & $\begin{array}{c}0.05 \mathrm{~cm}^{-1} \\
98.0 \mathrm{~cm}^{-1} \\
0.9\end{array}$ & & \\
\hline $\begin{array}{c}\text { Parietal } \\
\text { peritoneum } \\
\text { muscle tissue }\end{array}$ & $\begin{array}{l}\mu_{a} \\
\mu_{s} \\
g_{f}\end{array}$ & $\begin{array}{c}2.2 \mathrm{~cm}^{-1} \\
19.2 \mathrm{~cm}^{-1} \\
0.8\end{array}$ & & \\
\hline $\begin{array}{l}\text { Bone } \\
\text { (ribs) }\end{array}$ & $\begin{array}{c}\mu_{a} \\
\mu_{s} \\
g_{f} \\
r\end{array}$ & $\begin{array}{c}0.8 \mathrm{~cm}^{-1} \\
309.6 \mathrm{~cm}^{-1} \\
0.93 \\
0.05 \mathrm{~cm}\end{array}$ & & \\
\hline
\end{tabular}

a Obtained from reference [27]. ${ }^{\mathrm{b}}$ Obtained from reference [22]. ${ }^{\mathrm{c}}$ Initial concentration of singlet oxygen leading to cell death.

As is well known, the central region of most tumors contains mainly dead cells (necrotic core) while its periphery is poorly oxygenated (hypoxic area) [38]. In order to qualitatively simulate this phenomenon, the tumor oxygenation was considered to gradually decline until reaching zero values in its center. The formula empirically created for this purpose is:

$$
g(x, z)=g_{0}+\left(\frac{-0.878}{\sqrt{\frac{\pi}{2}}}\right) \cdot \exp \left(-10 \cdot\left(\frac{r}{0.2}\right)^{2}\right)
$$

\subsection{PPTT Model}

\subsubsection{Computational Simulation}

The "Radiative Beam in Absorbing Media" of COMSOL, based on the solution of the Beer-Lambert equation, was used to model the light propagation into the tissues and its interactions with the NPs. The corresponding module for heat transfer in biological media "Bioheat Transfer", which solves the bioheat equation (see Equation (5)) using Pennes' approximation, was used for the assessment of thermal interactions into the modeled mouse. The NPs-doped area was set as the "Heat Source".

$$
\rho C_{p} \frac{\partial T}{\partial t}+\nabla \boldsymbol{q}=\rho_{b} C_{p, b} \omega_{b}\left(T_{b}-T\right)+Q_{r a d}+Q_{m e t},
$$

where, $(\rho)$ is the density, $\left(C_{p}\right)$ is the specific heat capacity at constant pressure and $(T)$ is the absolute temperature of the tissue. Moreover, $(q)$ is the heat flux by conduction in the tissue, $\left(\rho_{b}\right)$ is the blood density, $\left(C_{p, b}\right)$ is the blood specific heat capacity at constant pressure, $\left(\omega_{b}\right)$ is the blood perfusion rate and $\left(T_{b}\right)$ is the arterial blood temperature. Finally, $\left(Q_{\mathrm{rad}}\right)$ and $\left(Q_{m e t}\right)$ are the radiation and metabolic heat sources, respectively. Since when modeling hyperthermic treatments, the metabolic heat source term is generally significantly lower than the radiation one (the NPs in this case) it may be neglected [39]. The values of the above parameters regarding blood were extracted from reference [39]. 
The virtual mouse was modeled on dimensions that correspond to reality. It is worth noting that air was not taken into account as a solid structure during the model simulation, in order to save computing resources. Instead, the heat flux from the skin to the environment was assessed via Newton's law for heat convection. Moreover, another way to conserve computing resources was utilized in the present study. More specifically, the simulation was constricted to the area surrounding the tumor and structures were sited away, as the head, the abdomen and the tail were excluded from calculations. The mesh size was set to "finer", since smaller mesh sizes resulted in significantly increased computational times but without noticeable temperature differentiations in the mouse model. The maximum and minimum element sizes created via the above procedure were 0.191 and $0.014 \mathrm{~cm}$, respectively.

\subsubsection{Nanoparticles and Parameters}

Gold nanoshells JSD0035 (NanoXact ${ }^{\mathrm{TM}}$ ) were assumed to induce hyperthermia (total diameter: $151 \mathrm{~nm}$, core diameter: $119 \mathrm{~nm}$ ). They were chosen as they have a polyethylene glycol (PEG) coating (a polyether compound consisting of repeating ethylene oxide units). This coating, which is often used in medical products [40], is considered a safe, stable substance that does not trigger an immune system response [41]. In addition, it allows the production of homogeneous aqueous solutions, which are of great importance for their injection into the animal's body. Finally, due to the neutral/slightly negative surface charge of PEG, it is considered suitable for in vivo use [41,42]. Regarding the time interval between the NPs administration and irradiation, it corresponded to a direct treatment application. The reason for this model selection was to avoid the diffusion of nanoparticles in the periphery of the tumor and in the surrounding healthy tissues and, therefore, the subsequent, undesirable heating of non-cancer areas.

As it is well known, according to Mie's theory [43], when a light beam interacts with a nanoparticle, absorption and scattering phenomena are observed, which are described by the absorption $\left(S_{a b s}\right)$ and scattering $\left(S_{s c a}\right)$ cross-sections, respectively. In case of coincidence between the beam wavelength and the wavelength of maximum absorption of the nanostructures, the attenuation of the beam can be practically attributed only to absorption $[9,44]$. Hence, the temperature increase of a NPs-doped volume can be evaluated as if it was an area of increased absorption coefficient $\left(\mu_{a}\right)$. The total $\mu_{a}$ value can be calculated as the sum of the absorption coefficients of the NPs $\left(\mu_{a, N P s}\right)$ and the surrounding material [45]. In this study, the former was assessed through Equation (6) [46]:

$$
\mu_{\alpha, N P s}=S_{a b s} \cdot N
$$

where, $\left(S_{a b s}\right)$ is the absorption cross-section and $(N)$ the number density of the NPs. The $S_{a b s}$ was set at $1.23 \cdot 10^{4} \mathrm{~nm}^{2}$, according to the online calculator of the NPs manufacturer (Mie Theory Calculator: https:/ / nanocomposix.com/pages/mie-theory-calculator, accessed on 10 October 2021). The properties of the tumor area containing NPs were calculated using Equation (7) [47]:

$$
x_{e f f}=x_{N P_{s}} \cdot f+x_{\text {tumor }} \cdot(1-f)
$$

where, $(x)$ stands for the calculated parameter (density $-\rho$, thermal conductivity $-k$, or specific heat capacity at constant pressure $-C_{p}$ ) and $(f)$ for the NPs volume fraction. For the above calculations NPs were assumed as solid gold spheres. As for the values of the rest properties used in calculations, they are summarized in Table 3. 
Table 3. Tissue properties of the simulation model.

\begin{tabular}{ccccc}
\hline Tissue & $\mu_{\boldsymbol{a}}\left(\mathbf{c m}^{-\mathbf{1}}\right)$ & $\begin{array}{c}\boldsymbol{\rho}\left(\mathbf{k g} / \mathbf{m}^{\mathbf{3}}\right) \\
{[48]}\end{array}$ & $\begin{array}{c}k \mathbf{W} /(\mathbf{m} \cdot \mathbf{K}) \\
{[49]}\end{array}$ & $\begin{array}{c}\left.\boldsymbol{C}_{\boldsymbol{p}}(\mathbf{J} / \mathbf{( k g} \cdot \mathbf{K})\right) \\
{[50]}\end{array}$ \\
\hline Tumor $^{\mathrm{a}}$ & 0.06 & 1150 & 0.56 & 4200 \\
NPs $^{\mathrm{b}}$ & 7.52 & 998 & 0.64 & 4180 \\
Skin & $1.26[32]$ & 1090 & 0.58 & 2291 \\
Heart & $0.98[51]$ & 1060 & 0.56 & 2291 \\
Lungs & $1.06[52]$ & 260 & 0.39 & 3890 \\
Liver & $5.7[53]$ & 1060 & 0.52 & 3620 \\
Muscle & $2.4[32]$ & 1000 & 0.49 & 3550 \\
Bone & $0.21[54]$ & 1400 & 0.32 & 1313 \\
Spleen & $1.26[54]$ & 1060 & 0.53 & 3720 \\
\hline
\end{tabular}

a Data extracted from reference [34]. ${ }^{\mathrm{b}}$ Data calculated according to Equations (6) and (7).

According to Table 4, the virtual application of the nanoparticles was performed with a single injection in the deepest available tumor area [55,56] (see Figure 2), via a $5 \mu \mathrm{L}$ aqueous solution $[55,56]$. This location was chosen based on the fact that the upper tumor layers would have been necrotized due to the PDT and as a result, the PPTT action would be needed at the lower cancer areas. The irradiation was performed immediately after injection, in order to avoid diffusion of NPs to the surrounding tissue, using a laser source $(\lambda=808 \mathrm{~nm}$ ), with spot radius $r=3.2 \mathrm{~mm}$, in order to make the study more realistic (due to the existence of such a source in our laboratory). The aim was to reach an average tumor temperature of $48-49^{\circ} \mathrm{C}$ in order to: (1) exceed $48^{\circ} \mathrm{C}$ that was set as the acute necrosis temperature threshold [10], (2) to avoid cancer areas with temperature values below $\sim 43^{\circ} \mathrm{C}$ (and therefore to develop resistance to treatment) [57], (3) the irradiation duration (and therefore anesthesia, in real word) to be as short as possible and (4) to be in line with the data of the respective studies listed in Table 4. Furthermore, the high temperature-short irradiation time combination prevented apoptotic cell death phenomena.

Table 4. Basic parameter values of in vivo PPTT in mice.

\begin{tabular}{cccccc}
\hline $\begin{array}{c}\text { Fluence } \\
\text { Rate } \\
\left(\mathbf{W} / \mathbf{c m}^{\mathbf{2}}\right)\end{array}$ & $\begin{array}{c}\text { Irradiation } \\
\text { Time } \\
(\mathbf{m i n})\end{array}$ & $\begin{array}{c}\text { Nanoparticle } \\
\text { Concentration }\end{array}$ & $\begin{array}{c}\text { Injected } \\
\text { Volume } \\
(\boldsymbol{\mu L})\end{array}$ & $\begin{array}{c}\text { Area/Way of } \\
\text { Injection }\end{array}$ & Refs. \\
\hline- & 6.7 & $3.6 \cdot 10^{12} \mathrm{prtcl} / \mathrm{mL}$ & 30 & Lymph nodes & {$[58]$} \\
4 & 3 & $2.4 \cdot 10^{11} \mathrm{prtcl} / \mathrm{mL}$ & 100 & Tail vein & {$[59]$} \\
4 & 6 & $1.4 \cdot 10^{10} \mathrm{prtcl} . / \mathrm{mL}$ & $20-50$ & Interstitial & {$[60]$} \\
0.8 & 10 & $80 \mu \mathrm{g} / \mathrm{ml}$ & - & Tail vein & {$[61]$} \\
1 & 5 & $10 \mathrm{mg} / \mathrm{kg}$ & - & Tail vein & {$[62]$} \\
1 & 2 & $27.5 \mathrm{pM}$ & 10 & Tumor & {$[55]$} \\
$1.7-1.9$ & 10 & $120 \mathrm{OD}$ & 100 & Tail vein & {$[63]^{\mathrm{b}}$} \\
$0.9-1.1$ & 10 & $40 \mathrm{OD}$ & 15 & Tumor & \\
\hline
\end{tabular}

a As reported in each study. ${ }^{b}$ The two last entries of the table are retrieved from reference [63]. 


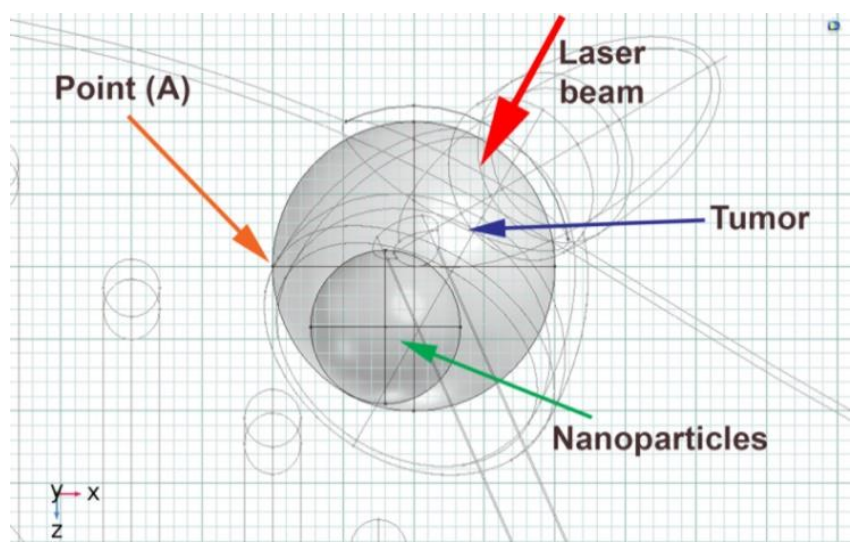

Figure 2. Position of the tumor, the area doped with nanoparticles and the point (A) of calculations at the $x-z$ plane. The laser beam direction is also noted.

As it can be seen from Table 4, the data of the parameters related to in vivo PPTT in mice present significant variations in literature, demonstrating the lack of a robust dosimetry in this field. Hence, the laser power and the treatment duration were parameterized in order to evaluate their optimal values, for instant necrosis induction due to a step temperature rise. Through the use of a previous developed model [64] and the "Parametric sweep" method of COMSOL, the temperature rise in a point of interest (A) (see Figure 2) was calculated. The location of the point (A) was chosen in a manner that it would be away from the NPs area (to account for a non-perfect scenario) and deep enough into the tumor, where the PDT action would not be expected to be efficient. The laser power values studied were in the range of 400 to $550 \mathrm{~mW}$ and treatment durations up to $5 \mathrm{~min}$, using a $5 \mathrm{~s}$ time step. This method provided a first approximation, in order to exclude any inadequate combinations and also to roughly estimate the best treatment time for each laser power value (that the temperature reaches $48{ }^{\circ} \mathrm{C}$ ). Afterwards, the average, maximum and minimum temperature in the tumor and the healthy tissues of interest were calculated. Finally, PPTT was assessed using the best of the above combinations, at a $1 \mathrm{~s}$ time step, to increase accuracy. Based on this procedure and the spatial distribution of necrotic tissue (using the "Instant necrosis indicator" of COMSOL), the optimum laser power and treatment time were defined. It should be noted that the NPs concentration was set at $6.1 \times 10^{10}$ particles $/ \mathrm{mL}$, in order to achieve a step temperature gradient and hence, a local hyperthermic distribution.

\subsection{Combined PPTT-PDT Model}

The PPTT-PDT combination was assessed via fusion of the necrotized area induced by each treatment. The images were analyzed using ImageJ software (v.1.53e) [65]. The total necrotic area percentage was calculated as the sum of the respective percentage of each therapy.

\section{Results}

\subsection{PDT Results}

The results of the PDT computational simulation are presented in Figure 3. As shown in part (a) of the figure, the fluence rate of the incident radiation was approximately $334 \mathrm{~mW} / \mathrm{cm}^{2}$, in agreement with the algebraically calculated one $\left(\sim 333 \mathrm{~mW} / \mathrm{cm}^{2}\right)$. As for the tumor surface, the scattered photons contributed to the local increase of the fluence rate by $\sim 44 \%$, which was also expected from the literature [60]. The mean fluence rate in the whole tumor was calculated at $229.3 \mathrm{~mW} / \mathrm{cm}^{2}$. The spatial distribution of $\left[{ }^{1} \mathrm{O}_{2}\right]_{r x}$ (see Figure $3 b$ ) was proportional to the fluence rate of the transmitted radiation, with its value fluctuating at an average of $440 \mu \mathrm{M}$ in the upper and $310 \mu \mathrm{M}$ in the lower hemisphere of the tumor volume, respectively. The maximum recorded value of $\left[{ }^{1} \mathrm{O}_{2}\right]_{r x}$ was $443 \mu \mathrm{M}$, which is 
in the same order of magnitude with the corresponding value reported by Beeson et al. [23]. Since the center of the tumor was assumed to be necrotic and surrounded by a hypoxic region (see Figure $3 \mathrm{c}$ ), the values of $\left[{ }^{1} \mathrm{O}_{2}\right]_{r x}$ decreased accordingly to the available molecular oxygen. Hence, the $54.8 \%$ of the tumor was evaluated as necrotized, in a crescent-shaped aspect, with a maximum estimated necrosis depth of $0.25 \mathrm{~cm}$ and a maximum necrotic diameter of $0.4 \mathrm{~cm}$, in agreement with literature [29]. It is of great importance to note that the above percentage corresponded to the oxygen supply reduction values that were assumed, in order to qualitatively and not quantitatively study the PDT action.

(a)

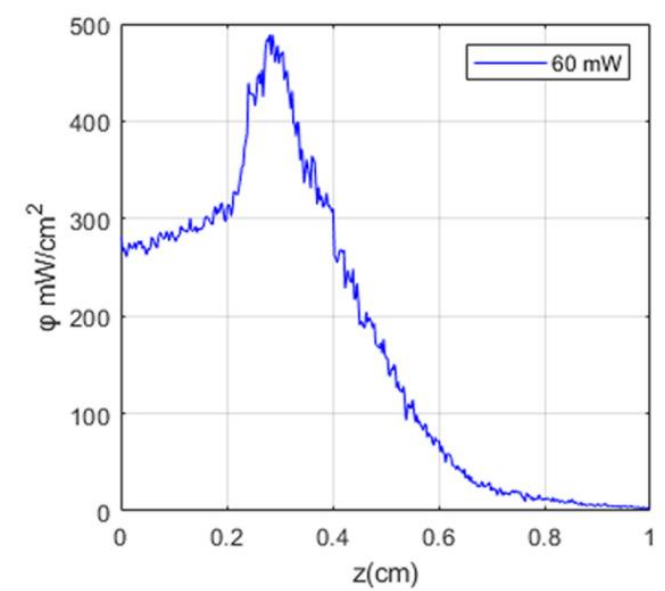

(c)

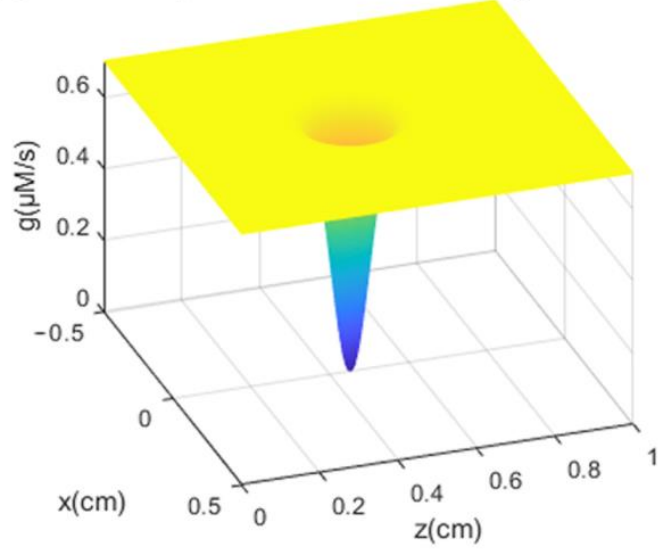

(b) Spatial distribution of $\left[{ }^{1} \mathrm{O}_{2}\right]_{r x}$

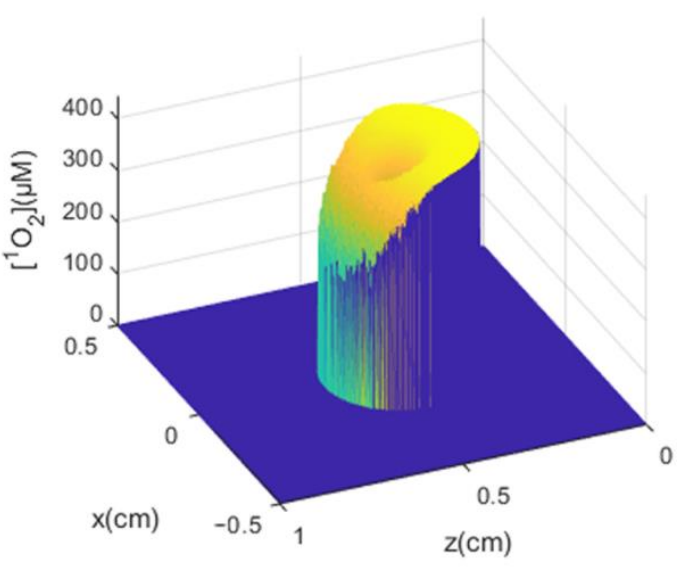

(d) Spatial distribution of necrotic area

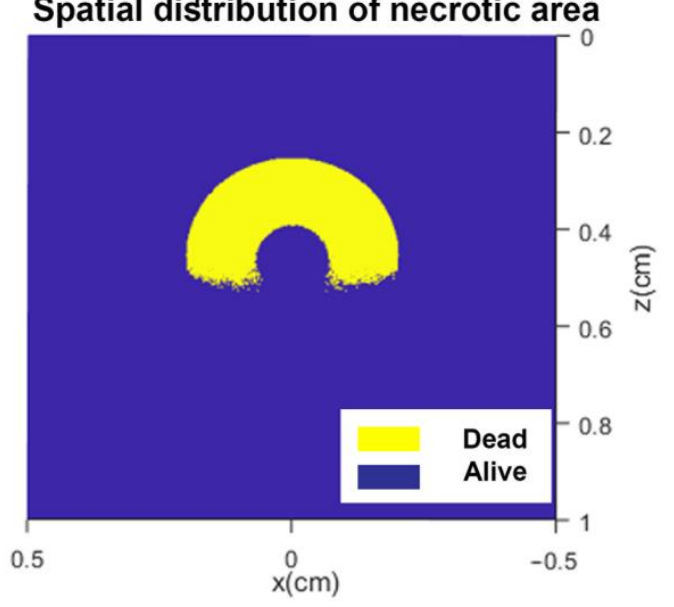

Figure 3. Results of the PDT simulation for 13.369 .517 photons. (a) Fluence rate at $z$ axis, at $x=0$. (b) Spatial distribution of the of produced $\left[{ }^{1} \mathrm{O}_{2}\right]_{r x}$. (c) Spatial distribution of the oxygen supply rate, in order to simulate the oxygen perfusion in the tumor. (d) Spatial distribution of the necrotic tumor area.

\subsection{PPTT Results}

The results of the parametric study, which were in agreement with literature [34,66], are presented in Figure 4a. As it can be seen, the combinations exceeding, or being very close to, the $48^{\circ} \mathrm{C}$ threshold were the following: $550 \mathrm{~mW}$ and $90 \mathrm{~s}, 500 \mathrm{~mW}$ and $140 \mathrm{~s}$ and $450 \mathrm{~mW}$ and $295 \mathrm{~s}$. Regarding the above, the average, maximum and minimum temperature values evaluated in cancer and healthy tissues are presented in Figure $4 \mathrm{~b}-\mathrm{d}$. According to them, the combination achieving adequate temperature rise in the tumor, while the average, maximum and minimum temperatures recorded to the healthy tissues are the lowest ones, was the $550 \mathrm{~mW}$ and $90 \mathrm{~s}$. The only exceptions were the maximum temperatures recorded 
in the nearest rib and the skin, where the combination of $450 \mathrm{~mW}$ and $295 \mathrm{~s}$ resulted in slightly lower values $(-0.7 \%$ and $-0.2 \%$, respectively). Therefore, setting the laser power at $550 \mathrm{~mW}$ and taking into account the spatial distribution of tumor necrosis (Figure $5 \mathrm{a}, \mathrm{b}$ ), the optimum treatment time was assessed at $70 \mathrm{~s}$. At that time point, the average tumor temperature was $48.7^{\circ} \mathrm{C}$, the tumor necrosis was evaluated as adequate and all the organs were spared. Based on the results of Figure $5 \mathrm{a}$, the calculation of the necrotic area coverage was approximately $65 \%$ of the total tumor, at the $x-z$ plane.

(a)

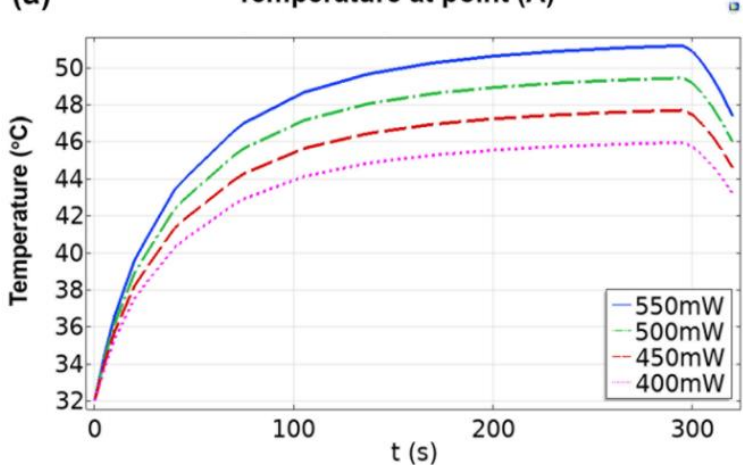

(c)

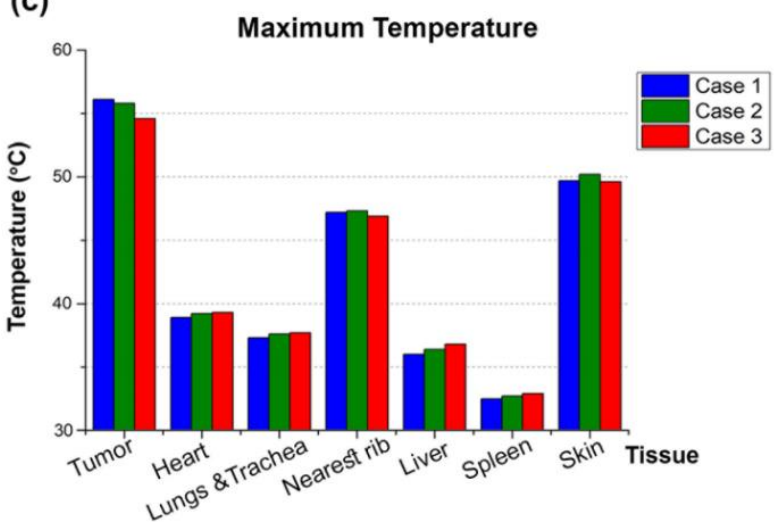

(b)

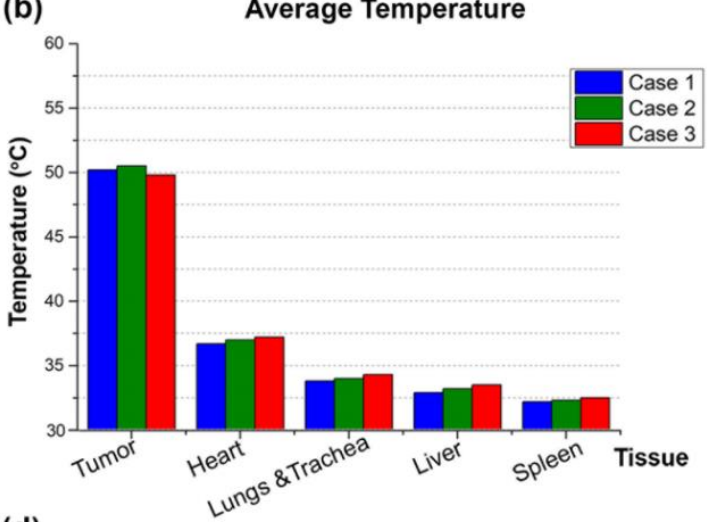

(d)

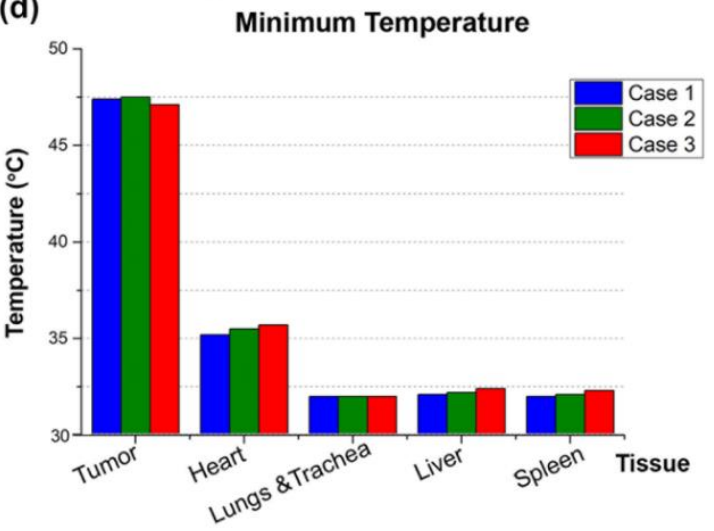

Figure 4. (a) Parametric study of the temperature rise in point (A) versus laser power and irradiation time. The $48{ }^{\circ} \mathrm{C}$ threshold is fully (or nearly fully) achieved for three combinations: Case 1 (blue): $550 \mathrm{~mW}$ and $90 \mathrm{~s}$, Case 2 (green): $500 \mathrm{~mW}$ and $140 \mathrm{~s}$ and Case 3 (red): $450 \mathrm{~mW}$ and $295 \mathrm{~s}$. For these cases the average (b), maximum (c) and minimum (d) temperature in the tumor and in healthy tissues are calculated.

(a)

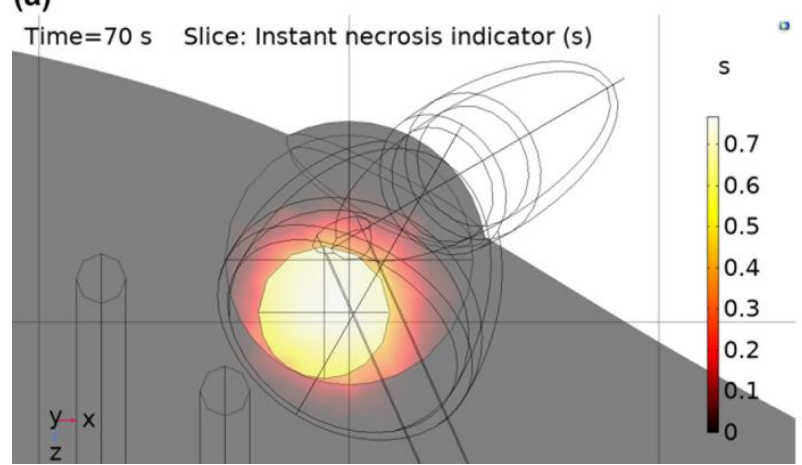

(b)

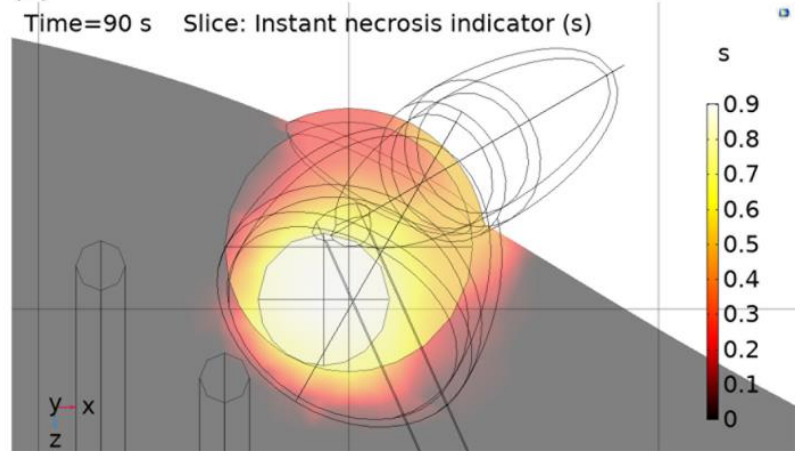

Figure 5. Spatial distribution of necrotic tissue at the $x-z$ plane, after (a) $70 \mathrm{~s}$ and (b) $90 \mathrm{~s}$ of treatment. In the 70 s scenario the skin is spared. 


\subsection{PPTT-PDT Combination Results}

The combination of the two therapies resulted in the fused image of Figure 6. The area of the necrotic region was estimated at approximately $99.3 \%$ of the total cancer area. Healthy tissue, such as, for example, the skin covering the tumor as well as the nearby ribs, was spared. Obviously, organs in distant sites, like the heart, lungs and trachea, liver and spleen were also spared. The only exception is an area of a few $\mathrm{mm}^{2}$ just beneath the tumor, which was also necrotized, as the results in Figure 6 show.

\section{PPTT - PDT combined necrosis}

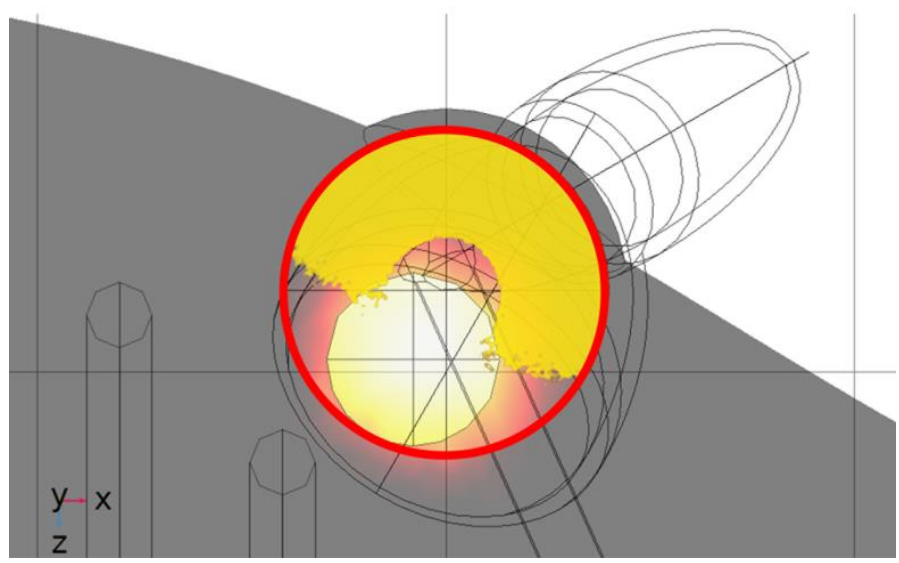

Figure 6. Necrotic area for the PPTT-PDT combined treatment scheme, as the fusion result of Figures $3 \mathrm{~d}$ and $5 \mathrm{a}$. The total necrotic percentage is $\sim 99.3 \%$. The tumor is highlighted in a red circle, for reasons of clarity.

\section{Discussion}

This study began by evaluating the lack of necrosis coverage in a PDT scheme. As far as the PDT therapeutic effect is concerned, it is shown that it is inextricably linked to the intensity of the radiation and the available molecular oxygen. The spatial distribution of the cytotoxic singlet oxygen (see Figure $3 b$ ) clearly demonstrated its dependence on these two main pillars of PDT. Thus, one can observe that firstly, $\left[{ }^{1} \mathrm{O}_{2}\right]_{r x}$ decreases when the tissue depth increases, since the fluence rate of the propagating radiation also decreases (see Figure 3a); secondly, the direct dependence of $\left[{ }^{1} \mathrm{O}_{2}\right]_{r x}$ on the amount of available molecular oxygen in the area. The "hole" in the central region of the $\left[{ }^{1} \mathrm{O}_{2}\right]_{r x}$ diagram, which corresponds to the "hole" observed in the spatial distribution of oxygenation (see Figure 3c), is indicative of the above correlation. As a consequence, the necrotized zone (see Figure 3d) follows the same pattern as $\left[{ }^{1} \mathrm{O}_{2}\right]_{r x}$. At this point, it should be reminded that the necrosis zone has been calculated based on a threshold concentration of cytotoxic molecules, the value of which has been derived from the literature and, thus, is not necessarily applicable in every in vivo experiment.

After a thorough parametric evaluation of the optimum treatment value combination and, as the results of the PPTT part of this study suggested, the recorded temperature in the tumor area could be high enough to destroy the cancer cells via instant necrosis. At the same time, the healthy tissue could be spared, since it was kept constantly below temperature values that could be potentially hazardous. Therefore, vital organs were considered to be safe. The only exception would be the skin above the tumor, if a longer treatment time was selected (see Figure $5 b$ ). Even in that case, a rather interesting way of skin cooling has been proposed by the team of T. Kodama [58], through the use of a water-cooled glass surface, in contact with the skin. At this point, the reader should have in mind that the upper tumor area does not have to be necrotized by PPTT, as the PDT acts on these layers. 
Regarding the desired temperature values in the tumor, they cannot be precisely defined since they depend on various parameters (e.g., tissue thermal properties, cancer type and geometry etc.) and on a thermal conduction. Certainly, the steeper the temperature gradient is, the more the fraction of necrotized cancer tissue to the healthy one is increased. The use of an acceptable high nanoparticles concentration [67] as well as an appropriate laser power value, can achieve the aforementioned, as the treatment time is minimized and thus, the heat does not have enough time to diffuse to the adjacent healthy tissues. Keeping in mind that PPTT was used in order to enhance PDT, the aim of the PPTT part of the study was to firstly achieve necrosis in the central and lower tumor areas. As was observed in the NPs area, values lower than $45^{\circ} \mathrm{C}$ (approximately) could be considered insufficient, since points in the periphery of the tumor would be exposed to significantly lower temperatures and therefore local disease control would probably not be achieved. On the other hand, due to the heat diffusion phenomena, temperatures higher than $50{ }^{\circ} \mathrm{C}$ (approximately) are expected to lead to potential damage to the surrounding healthy tissue as well as to unwanted protein denaturation. In this study case, the optimum average temperature in tumor was estimated at $48.7^{\circ} \mathrm{C}$.

The PPTT part of the therapeutic scheme takes advantage of the use of light of longer wavelengths, in the near-infrared region, as the one needed to achieve plasmonic effects, which do have a higher penetration depth. In contrast, PDT is applied using lower wavelengths and therefore has a lower penetration depth. As a result, PPTT can act in a complementary manner to PDT, in order to treat deeper sited and poorly oxygenated tumor areas. On the other hand, PDT presents highly localized effects, in contrast to PPTT, where heat diffusion takes place, affecting a larger area. Taking into account the total necrosis, it is obvious that a combination of the two therapies is rather promising. The necrotic tumor area percentages of $65 \%$ and $54.8 \%$ that PPTT and PDT alone recorded, respectively, were skyrocketed at $99.3 \%$ in the combinational scenario. Indeed, the aforementioned percentage is rather high and it cannot be directly compared to the literature, due to a lack of similar studies, to the best of our knowledge. On the other hand, there are papers that report complete tumor elimination, without recurrence, after in vivo photodynamic and photothermal therapy schemes $[68,69]$, making tumor destruction levels that correspond to the above percentage feasible. Finally, the healthy tissue sparing achieved is also very important, demonstrating the potential success of this treatment scheme.

An issue, which has not been yet sufficiently clarified, to the best of our knowledge, is the PPTT action in an area also exposed to PDT, although there are papers reporting the acceleration of the apoptotic processes [70], along with necrosis [68]. The vast majority of studies found in the literature use nanoparticle-photosensitizer complexes [1] rather than two independent modules/agents, as in the present study. In addition, an attempt to use a single light source (single wavelength therapy) to initiate both treatments at the same time is being made. Therefore, regarding the application order of the two therapies, some studies apply them simultaneously [71,72], while others apply first the PPTT and immediately after the PDT, in order to release the photosensitizer molecules from the nanostructures that have been attached [70]. As a result, a safe comparison with the published studies cannot be attempted. In any case, in a unified scheme, the photodynamic mechanism takes place almost instantaneously, while the photothermal follows, due to the time needed for temperature rise and diffusion [71].

\section{Conclusions}

In conclusion, the present study highlights the enhanced treatment outcome that the combination of PPTT and PDT can achieve, while maximizing the healthy tissue sparing effect and minimizing the drawbacks of each treatment as a monotherapy. Furthermore, the performed computational simulation is indicative of the contribution that in silico studies may have on PPTT and PDT dosimetry, as, for example, the values of the power of the light source and irradiation time can be optimized. Hence, we feel confident that this study can provide useful guidance in relevant, future in vivo experiments. Certainly, the assessment 
of the acceptable potential damage to the surrounding healthy tissues, in correlation with the control of the disease, is left to the respective physician (for patient applications) or veterinarian (for animal applications) who will after all have the general supervision of the treatment. Finally, the contribution of staff with the appropriate in-depth knowledge of physics in medicine (e.g., medical physicists) is crucial for the precise dosimetry of such novel, promising and certainly complex treatments.

Author Contributions: Conceptualization, G.K. and M.M.; methodology, G.K.; software, G.K. and E.C.; validation, G.K., E.C. and M.M.; formal analysis, G.K.; investigation, G.K. and E.C.; resources, G.K., E.C. and M.M.; data curation, G.K. and E.C.; writing-original draft preparation, G.K.; writingreview and editing, G.K., E.C. and M.M.; visualization, G.K. and E.C.; supervision, M.M.; project administration, G.K. and M.M. All authors have read and agreed to the published version of the manuscript.

Funding: This research received no external funding.

Institutional Review Board Statement: Not applicable.

Informed Consent Statement: Not applicable.

Data Availability Statement: The data that support the findings of this study are available from the corresponding author upon reasonable request.

Acknowledgments: The authors appreciate the kind suggestions of Georgios Tsigaridas regarding the modeling of nanoparticles in COMSOL Multiphysics ${ }^{\circledR}$ software.

Conflicts of Interest: The authors declare no conflict of interest.

\section{References}

1. Kareliotis, G.; Tremi, I.; Kaitatzi, M.; Drakaki, E.; Serafetinides, A.A.; Makropoulou, M.; Georgakilas, A.G. Combined radiation strategies for novel and enhanced cancer treatment. Int. J. Radiat. Biol. 2020, 96, 1087-1103. [CrossRef] [PubMed]

2. Agostinis, P.; Berg, K.; Cengel, K.A.; Foster, T.H.; Girotti, A.W.; Gollnick, S.O.; Hahn, S.M.; Hamblin, M.R.; Juzeniene, A.; Kessel, D.; et al. Photodynamic therapy of cancer: An update. CA Cancer J. Clin. 2011, 61, 250-281. [CrossRef]

3. Yang, W.; Liang, H.; Ma, S.; Wang, D.; Huang, J. Gold nanoparticle based photothermal therapy: Development and application for effective cancer treatment. Sustain. Mater. Technol. 2019, 22, e00109. [CrossRef]

4. Huang, X.; El-Sayed, M.A. Plasmonic photo-thermal therapy (PPTT). Alex. J. Med. 2011, 47, 1-9. [CrossRef]

5. Jain, S.; Hirst, D.G.; O'Sullivan, J.M. Gold nanoparticles as novel agents for cancer therapy. Br. J. Radiol. 2012, 85, 101-113. [CrossRef] [PubMed]

6. Kouloulias, V.; Triantopoulou, S.; Uzunoglou, N.; Pistevou-Gompaki, K.; Barich, A.; Zygogianni, A.; Kyrgias, G.; Kardamakis, D.; Pectasidis, D.; Kouvaris, J. Hyperthermia is now included in the NCCN clinical practice guidelines for breast cancer recurrences: An analysis of existing data. Breast Care 2015, 10, 109-116. [CrossRef]

7. Dimitriou, N.M.; Pavlopoulou, A.; Tremi, I.; Kouloulias, V. Prediction of gold nanoparticle and microwave-induced hyperthermia effects on tumor control via a simulation approach. Nanomaterials 2019, 9, e167. [CrossRef]

8. Zheng, Y.B.; Huang, T.J.; Desai, A.Y.; Wang, S.J.; Tan, L.K.; Gao, H.; Huan, A.C.H. Thermal behavior of localized surface plasmon resonance of $\mathrm{Au} / \mathrm{TiO}_{2}$ core/shell nanoparticle arrays. Appl. Phys. Lett. 2007, 90, 183117. [CrossRef]

9. Jauffred, L.; Samadi, A.; Klingberg, H.; Bendix, P.M.; Oddershede, L.B. Plasmonic heating of nanostructures. Chem. Rev. 2019, 119, 8087-8130. [CrossRef]

10. Ali, M.R.K.; Wu, Y.; El-Sayed, M.A. Gold-nanoparticle-assisted plasmonic photothermal therapy advances toward clinical application. J. Phys. Chem. C 2019, 123, 15375-15393. [CrossRef]

11. Von Tappeiner, H.; Jodlbauer, A. Uber die wirkung der photodynamischen (fluorescierenden) stoffe auf protozoen und enzyme. Dtsch. Arch. Klin. Med. 1904, 80, 427-487.

12. Von Tappeiner, H.; Jodlbauer, A. Die Sensiblilisierende Wirkung Fluoreszierender Substanzer Gesammte Untersuchungen uber Die Photodynamische Erscheinerung; Vogel: Leipzig, Germany, 1907.

13. Moan, J. On the diffusion length of singlet oxygen in cells and tissues. J. Photochem. Photobiol. B Biol. 1990, 6, 343-344. [CrossRef]

14. Huang, Z. A review of progress in clinical photodynamic therapy. Technol. Cancer Res. Treat. 2005, 4, 283-293. [CrossRef] [PubMed]

15. Usuda, J.; Kato, H.; Okunaka, T.; Furukawa, K.; Tsutsui, H.; Yamada, K.; Suga, Y.; Honda, H.; Nagatsuka, Y.; Ohira, T.; et al. Photodynamic therapy (PDT) for lung cancers. J. Thorac. Oncol. 2006, 1, 489-493. [CrossRef]

16. $\mathrm{Wu}, \mathrm{H}$.; Minamide, T.; Yano, T. Role of photodynamic therapy in the treatment of esophageal cancer. Dig. Endosc. 2019, 31, 508-516. [CrossRef] [PubMed] 
17. Mroz, P.; Yaroslavsky, A.; Kharkwal, G.B.; Hamblin, M.R. Cell death pathways in photodynamic therapy of cancer. Cancers 2011, 3, 2516-2539. [CrossRef] [PubMed]

18. Soriano, J.; Mora-Espí, I.; Alea-Reyes, M.E.; Pérez-García, L.; Barrios, L.; Ibáñez, E.; Nogués, C. Cell death mechanisms in tumoral and non-tumoral human cell lines triggered by photodynamic treatments: Apoptosis, necrosis and parthanatos. Sci. Rep. 2017, 7, 41340. [CrossRef]

19. Bacellar, I.O.L.; Tsubone, T.M.; Pavani, C.; Baptista, M.S. Photodynamic efficiency: From molecular photochemistry to cell death Int. J. Mol. Sci. 2015, 16, 20523-20559. [CrossRef]

20. Kareliotis, G.; Papachristou, M.; Priftakis, D.; Datseris, I.; Makropoulou, M. Computational study of necrotic areas in rat liver tissue treated with photodynamic therapy. J. Photochem. Photobiol. B 2019, 192, 40-48. [CrossRef]

21. Kareliotis, G.; Liossi, S.; Makropoulou, M. Assessment of singlet oxygen dosimetry concepts in photodynamic therapy through computational modeling. Photodiagn. Photodyn. Ther. 2018, 21, 224-233. [CrossRef]

22. Wang, K.K.; Finlay, J.C.; Busch, T.M.; Hahn, S.M.; Zhu, T.C. Explicit dosimetry for photodynamic therapy: Macroscopic singlet oxygen modeling. J. Biophotonics 2010, 3, 304-318. [CrossRef] [PubMed]

23. Beeson, K.W.; Parilov, E.; Potasek, M.; Kim, M.M.; Zhu, T.C. Validation of combined Monte Carlo and photokinetic simulations for the outcome correlation analysis of benzoporphyrin derivative-mediated photodynamic therapy on mice. J. Biomed. Opt. 2019, 24, 035006. [CrossRef]

24. Isabelle, M.; Klubben, W.; He, T.; Laughney, A.M.; Glaser, A.; Krishnaswamy, V.; Hoopes, P.J.; Hasan, T.; Pogue, B.W. Assessment of biophysical tumor response to PDT in pancreatic cancer using localized reflectance spectroscopy. Opt. Methods Tumor Treat. Detect. Mech. Tech. Photodyn. Ther. XX 2011, 7886, 78860S. [CrossRef]

25. Runnels, J.M.; Chen, N.; Ortel, B.; Kato, D.; Hasan, T. BPD-MA-mediated photosensitization in vitro and in vivo: Cellular adhesion and $\beta 1$ integrin expression in ovarian cancer cells. Br. J. Cancer 1999, 80, 946-953. [CrossRef]

26. Tong, Z.S.; Miao, P.T.; Liu, T.T.; Jia, Y.S.; Liu, X.D. Enhanced antitumor effects of BPD-MA-mediated photodynamic therapy combined with adriamycin on breast cancer in mice. Acta Pharmacol. Sin. 2012, 33, 1319-1324. [CrossRef] [PubMed]

27. Kim, M.M.; Penjweini, R.; Liang, X.; Zhu, T.C. Explicit macroscopic singlet oxygen modeling for benzoporphyrin derivative monoacid ring A (BPD)-mediated photodynamic therapy. J. Photochem. Photobiol. B Biol. 2016, 164, 314-322. [CrossRef] [PubMed]

28. Kim, M.M.; Penjweini, R.; Zhu, T.C. In vivo outcome study of BPD-mediated PDT using a macroscopic singlet oxygen model. In Proceedings of the SPIE BIOS, San Francisco, CA, USA, 7-12 February 2015; Volume 9308. [CrossRef]

29. Liu, B.; Liang, X.; Zhu, T. Singlet oxygen modeling of BPD mediated-PDT using COMSOL. In Proceedings of the 2012 COMSOL Conference, Boston, MA, USA, 3-5 October 2012

30. McMillan, D.D.; Chen, D.; Kim, M.M.; Liang, X.; Zhu, T.C. Parameter determination for singlet oxygen modeling of BPD-Mediated PDT. In Proceedings of the Optical Methods for Tumor Treatment and Detection: Mechanisms and Techniques in Photodynamic Therapy XXII, San Francisco, CA, USA, 2-7 February 2013; Volume 8568, p. 856810. [CrossRef]

31. Kareliotis, G.; Xanthopoulos, S.; Drakaki, E.; Papachristou, M.; Datseris, I.; Bouziotis, P.; Makropoulou, M. Photodynamic therapy of 4T1 tumors in NOD-SCID mice. arXiv 2020, arXiv:2008.03537v2.

32. Bashkatov, A.N.; Berezin, K.V.; Dvoretskiy, K.N.; Chernavina, M.L.; Genina, E.A.; Genin, V.D.; Kochubey, V.I.; Lazareva, E.N.; Pravdin, A.B.; Shvachkina, M.E.; et al. Measurement of tissue optical properties in the context of tissue optical clearing. J. Biomed. Opt. 2018, 23, 1-31. [CrossRef]

33. Sabino, C.P.; Deana, A.M.; Yoshimura, T.M.; da Silva, D.F.T.; França, C.M.; Hamblin, M.R.; Ribeiro, M.S. The optical properties of mouse skin in the visible and near infrared spectral regions. J. Photochem. Photobiol. B. 2016, 160, 72-78. [CrossRef]

34. Xu, Y.; Long, S.; Yang, Y.; Zhou, F.; Dong, N.; Yan, K.; Wang, B.; Zeng, Y.; Du, N.; Li, X.; et al. Mathematical simulation of temperature distribution in tumor tissue and surrounding healthy tissue treated by laser combined with indocyanine green. Theor. Biol. Med. Model. 2019, 16, 12. [CrossRef]

35. Jacques, S.L. Optical properties of biological tissues: A review. Phys. Med. Biol. 2013, 58, R37-R61. [CrossRef] [PubMed]

36. National Center for Biotechnology Information Compound Summary for CID 31296. Available online: https://pubchem.ncbi. nlm.nih.gov/compound/Visudyne (accessed on 22 November 2020).

37. Kim, M.M.; Ghogare, A.A.; Greer, A.; Zhu, T.C. On the in vivo photochemical rate parameters for PDT reactive oxygen species modeling. Phys. Med. Biol 2017, 62, R1-R48. [CrossRef] [PubMed]

38. Makropoulou, M. Cancer and electromagnetic radiation therapy: Quo Vadis? arXiv 2016, arXiv:1602.02077.

39. Bost, C. Heat Transfer in Biological Tissue with Thermal Damage Analysis. Available online: https://www.comsol.com/blogs/ heat-transfer-in-biological-tissue-with-thermal-damage-analysis/ (accessed on 20 February 2022).

40. Weissig, V.; Pettinger, T.K.; Murdock, N. Nanopharmaceuticals (Part 1): Products on the market. Int. J. Nanomed. 2014, 9 , 4357-4373. [CrossRef] [PubMed]

41. Suk, J.S.; Xu, Q.; Kim, N.; Hanes, J.; Ensign, L.M. PEGylation as a strategy for improving nanoparticle-based drug and gene delivery. Adv. Drug Deliv. Rev. 2016, 99, 28-51. [CrossRef]

42. Stiufiuc, R.; Iacovita, C.; Nicoara, R.; Stiufiuc, G.; Florea, A.; Achim, M.; Lucaciu, C.M. One-step synthesis of PEGylated gold nanoparticles with tunable surface charge. J. Nanomater. 2013, 2013, 146031. [CrossRef]

43. Carrillo-Cazares, A.; Jiménez-Mancilla, N.P.; Luna-Gutiérrez, M.A.; Isaac-Olivé, K.; Camacho-López, M.A. Study of the optical properties of functionalized gold nanoparticles in different tissues and their correlation with the temperature increase. J. Nanomater. 2017, 2017, 3628970. [CrossRef] 
44. Cheong, S.-K.; Krishnan, S.; Cho, S.H. Modeling of plasmonic heating from individual gold nanoshells for near-infrared laser-induced thermal therapy. Med. Phys. 2009, 36, 4664-4671. [CrossRef]

45. Vignion-Dewalle, A.-S.; Betrouni, N.; Tylcz, J.-B.; Vermandel, M.; Mortier, L.; Mordon, S. Comparison of three light doses in the photodynamic treatment of actinic keratosis using mathematical modeling. J. Biomed. Opt. 2015, 20, 58001. [CrossRef]

46. Pattani, V.P.; Tunnell, J.W. Nanoparticle-mediated photothermal therapy: A comparative study of heating for different particle types. Lasers Surg. Med. 2012, 44, 675-684. [CrossRef]

47. Javidi, M.; Heydari, M.; Attar, M.M.; Haghpanahi, M.; Karimi, A.; Navidbakhsh, M.; Amanpour, S. Cylindrical agar gel with fluid flow subjected to an alternating magnetic field during hyperthermia. Int. J. Hyperth. 2015, 31, 33-39. [CrossRef] [PubMed]

48. Zhang, X.; Xie, X.; Qu, D.; Ning, J.; Zhou, H.; Pan, J.; Yang, G. Determining organ dose conversion coefficients for external neutron irradiation by using a voxel mouse model. J. Radiat. Res. 2016, 57, 182-188. [CrossRef] [PubMed]

49. Foundation for Research on Information Technologies in Society (IT'IS) Thermal Conductivity. Available online: https://itis swiss/virtual-population/tissue-properties/database/thermal-conductivity/ (accessed on 15 November 2021).

50. Giering, K.; Lamprecht, I.; Minet, O. Specific heat capacities of human and animal tissues. In Laser-Tissue Interaction and Tissue Optics; Delacretaz, G.P., Steiner, R.W., Svaasand, L.O., Albrecht, H., Meier, T.H., Eds.; SPIE: Bellingham, WA, USA, 1996; Volume 2624, pp. 188-197.

51. Wilson, B.C. Measurement of Tissue Optical Properties: Methods and Theories. In Optical-Thermal Response of Laser-Irradiated Tissue; Welch, A.J., Van Gemert, M.J.C., Eds.; Springer: Boston, MA, USA, 1995; pp. 233-303. ISBN 978-1-4757-6092-7.

52. Durkee, M.S.; Nooshabadi, F.; Cirillo, J.D.; Maitland, K.C. Optical model of the murine lung to optimize pulmonary illumination. J. Biomed. Opt. 2018, 23, 1-12. [CrossRef] [PubMed]

53. Parsa, P.; Jacques, S.L.; Nishioka, N.S. Optical properties of rat liver between 350 and 2200 nm. Appl. Opt. 1989, 28, 2325-2330. [CrossRef] [PubMed]

54. Liu, K.; Lu, Y.; Tian, J.; Qin, C.; Yang, X.; Zhu, S.; Yang, X.; Gao, Q.; Han, D. Evaluation of the simplified spherical harmonics approximation in bioluminescence tomography through heterogeneous mouse models. Opt. Express 2010, 18, 20988-21002. [CrossRef]

55. Yang, T.D.; Choi, W.; Yoon, T.H.; Lee, K.J.; Lee, J.-S.; Joo, J.H.; Lee, M.-G.; Yim, H.S.; Choi, K.M.; Kim, B.; et al. In vivo photothermal treatment by the peritumoral injection of macrophages loaded with gold nanoshells. Biomed. Opt. Express 2015, 7, 185-193. [CrossRef]

56. Gutwein, L.G.; Singh, A.K.; Hahn, M.A.; Rule, M.C.; Knapik, J.A.; Moudgil, B.M.; Brown, S.C.; Grobmyer, S.R. Fractionated photothermal antitumor therapy with multidye nanoparticles. Int. J. Nanomed. 2012, 7, 351-357. [CrossRef]

57. Basu, S.; Binder, R.J.; Suto, R.; Anderson, K.M.; Srivastava, P.K. Necrotic but not apoptotic cell death releases heat shock proteins, which deliver a partial maturation signal to dendritic cells and activate the NF-kappa B pathway. Int. Immunol. 2000, 12, 1539-1546. [CrossRef]

58. Sugiura, T.; Matsuki, D.; Okajima, J.; Komiya, A.; Mori, S.; Maruyama, S.; Kodama, T. Photothermal therapy of tumors in lymph nodes using gold nanorods and near-infrared laser light with controlled surface cooling. Nano Res. 2015, 8, 3842-3852. [CrossRef]

59. O'Neal, D.P.; Hirsch, L.R.; Halas, N.J.; Payne, J.D.; West, J.L. Photo-thermal tumor ablation in mice using near infrared-absorbing nanoparticles. Cancer Lett. 2004, 209, 171-176. [CrossRef]

60. Hirsch, L.R.; Stafford, R.J.; Bankson, J.A.; Sershen, S.R.; Rivera, B.; Price, R.E.; Hazle, J.D.; Halas, N.J.; West, J.L. Nanoshellmediated near-infrared thermal therapy of tumors under magnetic resonance guidance. Proc. Natl. Acad. Sci. USA 2003, 100, 13549-13554. [CrossRef] [PubMed]

61. Zhang, Y.; Sun, X.; Nan, N.; Cao, K.-X.; Ma, C.; Yang, G.-W.; Yu, M.-W.; Yang, L.; Li, J.-P.; Wang, X.-M.; et al. Elemene inhibits the migration and invasion of 4T1 murine breast cancer cells via heparanase. Mol. Med. Rep. 2017, 16, 794-800. [CrossRef] [PubMed]

62. Yang, Y.; Zhu, D.; Liu, Y.; Jiang, B.; Jiang, W.; Yan, X.; Fan, K. Platinum-carbon-integrated nanozymes for enhanced tumor photodynamic and photothermal therapy. Nanoscale 2020, 12, 13548-13557. [CrossRef]

63. Dickerson, E.B.; Dreaden, E.C.; Huang, X.; El-Sayed, I.H.; Chu, H.; Pushpanketh, S.; McDonald, J.F.; El-Sayed, M.A. Gold nanorod assisted near-infrared plasmonic photothermal therapy (PPTT) of squamous cell carcinoma in mice. Cancer Lett. 2008, $269,57-66$. [CrossRef] [PubMed]

64. Kareliotis, G.; Kalkou, M.; Tsigaridas, G.; Makropoulou, M.; Serafetinides, A.A. Assessing temperature increase during photodynamic therapy: A simulation model. J. Phys. Conf. Ser. 2021, 1859, 12048. [CrossRef]

65. Rasband, W.S. ImageJ; U.S. National Institutes of Health: Bethesda, MD, USA, 1997-2018. Available online: https://imagej.nih. gov/ij/ (accessed on 5 February 2021).

66. Chen, Q.; Xu, L.; Liang, C.; Wang, C.; Peng, R.; Liu, Z. Photothermal therapy with immune-adjuvant nanoparticles together with checkpoint blockade for effective cancer immunotherapy. Nat. Commun. 2016, 7, 13193. [CrossRef]

67. Dimitriou, N.M.; Tsekenis, G.; Balanikas, E.C.; Pavlopoulou, A.; Mitsiogianni, M.; Mantso, T.; Pashos, G.; Boudouvis, A.G.; Lykakis, I.N.; Tsigaridas, G.; et al. Gold nanoparticles, radiations and the immune system: Current insights into the physical mechanisms and the biological interactions of this new alliance towards cancer therapy. Pharmacol. Ther. 2017, 178, 1-17. [CrossRef]

68. Xu, W.; Qian, J.; Hou, G.; Wang, Y.; Wang, J.; Sun, T.; Ji, L.; Suo, A.; Yao, Y. A dual-targeted hyaluronic acid-gold nanorod platform with triple-stimuli responsiveness for photodynamic/photothermal therapy of breast cancer. Acta Biomater. 2019, 83, 400-413. [CrossRef] 
69. Yan, J.; Sun, H.; Li, J.; Qi, W.; Wang, H. A theranostic plaster combining photothermal therapy and photodynamic therapy based on chlorin e6/gold nanorods (Ce6/Au nrs) composite. Colloids Surf. A Physicochem. Eng. Asp. 2018, 537, 460-466. [CrossRef]

70. Jang, B.; Park, J.-Y.; Tung, C.-H.; Kim, I.-H.; Choi, Y. Gold nanorod-photosensitizer complex for near-infrared fluorescence imaging and photodynamic/photothermal therapy in vivo. ACS Nano 2011, 5, 1086-1094. [CrossRef]

71. Wang, S.; Huang, P.; Nie, L.; Xing, R.; Liu, D.; Wang, Z.; Lin, J.; Chen, S.; Niu, G.; Lu, G.; et al. Single continuous wave laser induced photodynamic/plasmonic photothermal therapy using photosensitizer-functionalized gold nanostars. Adv. Mater. 2013, 25, 3055-3061. [CrossRef] [PubMed]

72. Sun, Q.; You, Q.; Pang, X.; Tan, X.; Wang, J.; Liu, L.; Guo, F.; Tan, F.; Li, N. A photoresponsive and rod-shape nanocarrier: Single wavelength of light triggered photothermal and photodynamic therapy based on AuNRs-capped \& Ce6-doped mesoporous silica nanorods. Biomaterials 2017, 122, 188-200. [CrossRef] [PubMed] 